\title{
Detecting climate change effects on forest ecosystems in Southwestern Romania using Landsat TM NDVI data
}

\author{
Remus PRAVALIE ${ }^{1}$, Igor SÎRODOEV² ${ }^{2}$ Daniel PEPTENATU ${ }^{3}$ \\ 1. Bucharest University - Faculty of Geography, 14-12 Nicolae Bălcescu Str., Romania; \\ 2. Institute of Ecology and Geography, Moldavian Academy of Sciences, Republic of Moldova; \\ 3. Bucharest University - Interdisciplinary Center for Advanced Research on Territorial Dynamics, 3-12 Regina \\ Elisabeta Str., Bucharest, Romania
}

\begin{abstract}
Nowadays, Southwestern Romania faces a large-scale aridization of the climate, revealed by the rise of temperatures and the decline of the amount of precipitations, with negative effects visible, among others, in the desiccation of forest vegetation. The present study means to identify the changes that occurred, quality-wise, in the past two decades (1990-2011) in forest vegetation in Southwestern Romania, and to establish the link between those changes and extant thermal stress in the region, whose particular features are high average annual and seasonal temperatures. In order to capture the evolution in time of climate aridization, a first step consisted in using climate data, the temperature and precipitation parameters from three weather stations; these parameters were analyzed both individually and as aridity indexes (De Martonne and UNEP). In order to quantify the changes in forest vegetation, NDVI indexes were used and analyzed, starting off from Landsat satellite images, acquired at three distinct moments in time, 1990, 2000 and 2011. In order to identify the link between the changes of NDVI index values and regional thermal stress, a yardstick of climate changes, statistical correlations were established between the peak values of average annual temperatures, represented in space, and negative changes in the NDVI index, as revealed by the change-detection analysis. The results obtained indicated there is an obvious (statistically significant) connection between thermal stress and the desiccation (degradation) of forest species in the analyzed area, with false acacia (Robinia Pseudoacacia) the main species to be impacted.
\end{abstract}

Keywords: thermal stress; forest ecosystems; NDVI index; change detection analysis

\section{Introduction}

The rise of temperature and the drop of the average annual precipitations in numerous regions of the world are the main climate changes, which have accelerated predominantly in the past three decades (IPCC, 2007), which have brought to bear important pressure on for-

Received: 2013-08-12 Accepted: 2014-02-12

Author: Remus Pravalie, E-mail: pravalie_remus@yahoo.com; Igor Sîrodoev, E-mail: ingvarr_i@yahoo.com; Daniel Peptenatu, E-mail: peptenatu@yahoo.fr 
est ecosystems. Preserving the quality of forest ecosystems in an optimal environmental balance is of paramount importance, in the context where they fulfill a series of key functions such as climate regularization, hydrological functions, protection against soil erosion, pollution control, a scenic function and others (forest.jrc.ec.europa.eu). Forest ecosystems have captured the attention of scientists ever more often in the past few decades, in the context where the ecosystems have undergone important transformations against the background of global climate changes (Hanson and Weltzin, 2000; Dale et al., 2001; Keller et al., 2002; Archaux and Wolters, 2006; Iverson et al., 2007).

Nowadays, remote sensing analyses of forest ecosystem quality are some of the most frequently used instruments because they provide a series of benefits linked to being able to span large areas and providing rapid and high-resolution images, among others, although there are also certain problems linked to the compatibility, calibration, geometry and the continuity of the data (Deshayes et al., 2006). Temporal change detection analysis by means of the NDVI index is a remote-sensing method frequently used in current specialized analyses on the fluctuation of the quality of forest ecosystems or private vegetation overall (Gao and Dennis, 2001; Wang et al., 2003; Lee et al., 2008; Wang et al., 2008; Virtanen et al., 2010; Cui and Shi, 2010; Meng et al., 2011; Yang et al., 2011; Vogelmann et al., 2012). At the same time, the NDVI index is frequently used in the case of regions across the world that are suffering from desertification/aridization/drought, where the vegetation is permanently subject to severe climate conditions (thermal stress, high humidity deficit) (Li et al., 2004; Anyamba and Tucker, 2005; Barbosa et al., 2006; Sternberg et al., 2011; Liu et al., 2012).

The analyzed region, Southwestern Romania, is nowadays impacted by large-scale aridization, enhanced, particularly in the past two decades, by the synergic context of the global climate changes and soil deterioration, as a result of the flawed human administration of the land (Păltineanu et al., 2007; Peptenatu et al., 2013; Prăvălie, 2013a, 2013b, 2013c). The drop in the amount of precipitation and the rise of average annual temperatures have brought about important changes in the quality of forest ecosystems, as they have been suffering from drought across large areas in the past two or three decades. Therefore, desiccation may be seen as deterioration of forest ecosystems that, alongside changes brought about by anthropic pressure (deforestation), may create the conditions for a significant drop in the quality of ecosystem services (Prăvălie et al., 2013b). Preserving the quality of forest ecosystems is vitally important, as they fulfill key functions in that region, such as alleviating the negative effects of climate change, preserving optimal soil humidity, stabilization of the sand dunes in the region, fighting wind erosion, and agri-environmental functions by means of the forest belts, among others.

The present study means to detect the changes that occurred at the level of forest ecosystems by means of the NDVI index, as well as to establish a direct link between those changes and regional thermal stress, on the rise in the past few decades in the context of the global climate changes.

\section{Data and methods}

\subsection{Study area}

The study area coincides with Romania's Southwestern corner, spanning 113 administrative 
units. It is bordered by the Danube River (to the south and west), the Olt River (to the east), the Getic Plateau (to the northwest) and the Romanian Plain (to the northeast), with the western and eastern borders conditioned by the contour of the satellite scenes used as the source of the satellite images. It covers 736,723 hactares and most of it coincides with the Oltenia Plain (with the exception of the northwestern part, covering a small section of the Getic Plateau), a subdivision of the Romanian Plain.

As far as the climate parameters are concerned, the average annual temperatures and precipitations are characterized by a significant diversity across regions. According to the data available from three weather stations (Figure 1), the average annual temperatures stand at $12.2^{\circ} \mathrm{C}$ in Drobeta Turnu Severin, $11.3^{\circ} \mathrm{C}$ in Craiova and $11.9^{\circ} \mathrm{C}$ in Turnu Măgurele, while the average annual precipitations stand at $667.5 \mathrm{~mm}$ in Drobeta Turnu Severin, $514.1 \mathrm{~mm}$ in Craiova and 528.6 mm in Turnu Măgurele (1961-2009).

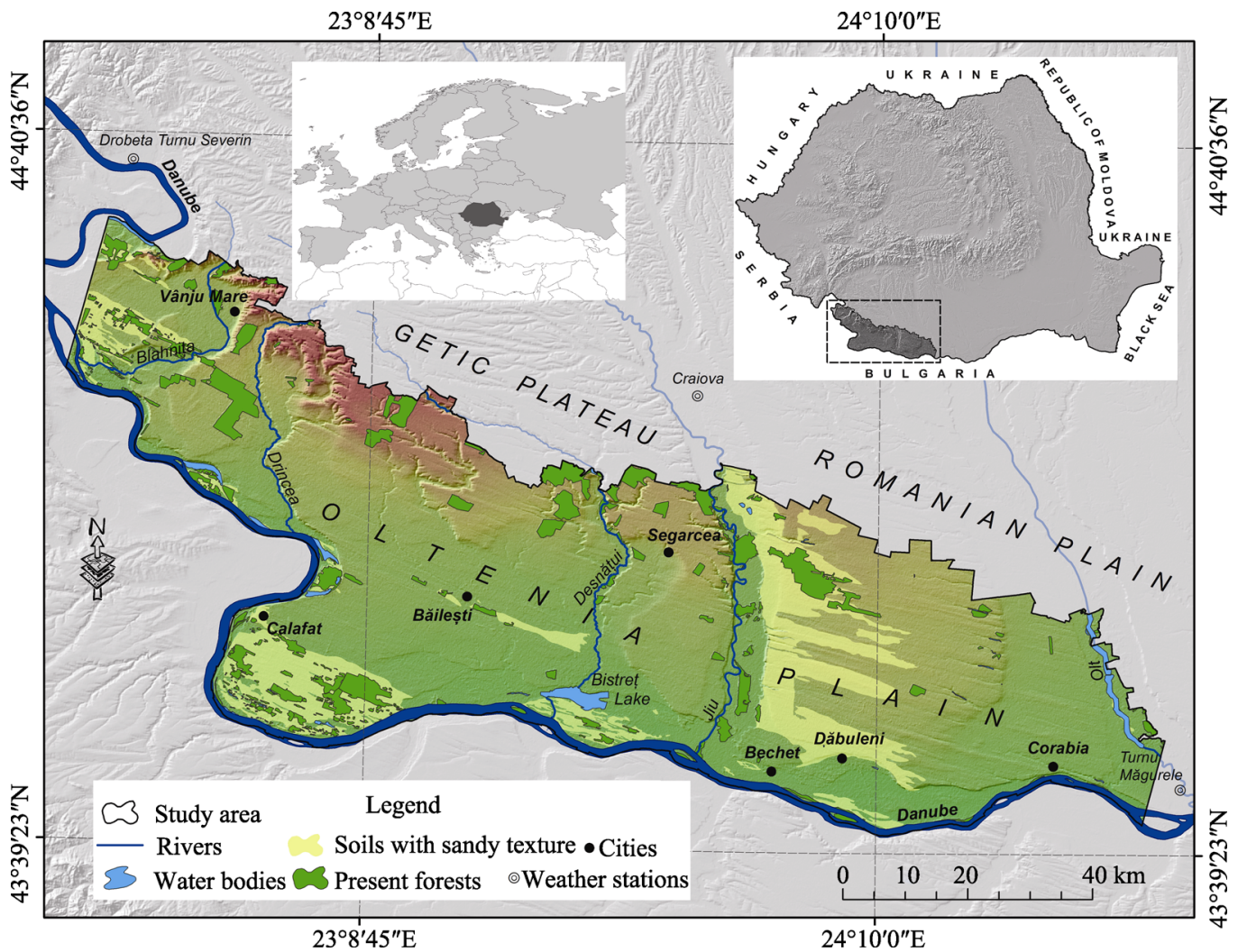

Figure 1 Location of the study area in Romania

From the point of view of the forest vegetation, it covers a total area of 56,330 hectares and it mainly consists of false acacia (Robinia pseudoacacia), downy oak ( $Q$. pubescens), Turkey oak $(Q$. cerris), Hungarian oak ( $Q$. frainetto), and pedunculate oak $(Q$. pedunculiflora) (Pătroescu, 2005). The biggest part of the forest ecosystem consists of acacia forests, as they were planted on very large surfaces in the past century with the goal of stabilizing the sandy soil (Traci, 1985; Dumitraşcu, 2006) that covers large areas in the southwestern part of the study area, as well as areas located west of the Blahnita and east of the Jiu rivers 
(Figure 1).

Planting false acacia in the region was meant as a strategic way of stabilizing the sandy soils, covering very large surfaces $(116,000$ ha, or $35 \%$ of the total 330,000 ha of sandy-soil areas in Romania), which had acted as a factor impacting on the local communities by way of the wind erosion. False acacia is a forest species that has adapted to severe environmental conditions, first of all thanks to its root system, well adapted to low-humidity conditions and able to reach down to high-depth groundwater, as a result of its considerable length. Another important feature concerns the very high nitrogen-fixation capacity, which allows the plant to grow normally even on sandy soils, lacking in nutritive elements (Holle et al., 2006; Moshki and Lamersdorf, 2011). From the point of view of the connection between climate conditions and false acacia's environmental needs, the optimal development of this forest species requires, in general, average annual temperatures in the $9-11^{\circ} \mathrm{C}$ range and precipitations above 400-500 mm a year (Calafat, Poiana Mare, Jiana forestry-planning documents).

In the past few decades, false-acacia forests have experienced important changes linked to deterioration (against the background of the intensification of drought and aridization, in the context of global climate change), and to aggressive anthropic interventions (deforestation), which led to the loss of important tracts of forested land, especially in the sandy-soil regions (Prăvălie et al., 2013b).

\subsection{Climate data}

The present study used monthly climate data, year-on-year, with a view to quantifying the climate's temporal fluctuation over a time span of five decades. Therefore, we obtained and processed average monthly temperature and precipitation data from the ECA\&D (European Climate Assessment \& Dataset) climate platform. The data originate from three weather stations located close to the study area (Drobeta Turnu Severin, Craiova and Turnu Măgurele) (Figure 1), and the analysis time span covers 49 years (1961-2009). Most of the data available encompassed the entire time span analyzed, with the exception of a few monthly records missing (at the Drobeta Turnu Severin and Turnu Măgurele stations) which were artificially extrapolated using the data available throughout from the Craiova station. In most cases, the determination quotient $\left(\mathrm{R}^{2}\right)$ exceeded 0.8 , and the correlation quotient ( $\mathrm{r}$ ) came close to 1 (above 0.9 ), so that the data artificially obtained that way were relevant as a result of the high correlation of the common set of data.

The data were processed on a monthly basis, year-on-year, using the vectorized-grid representation method (Cheval et al., 2003). This method, modified for the purposes of the present study, consists of the presence of a grid of parallel dots, arranged in 12 columns (the number of months) and 49 rows (the number of years in the time span analyzed, 1961-2009), each dot representing the value of the climate parameter matching the intersection of the row and column. For viewing, analysis and interpretation, the grid values (in shapefile format) were inserted in the GIS software, by means of ArcGIS 10.1 software's Spline method of insertion. At the same time, an analysis was conducted of the fluctuation of average monthly temperatures during the season of peak biological activity (May-August), a very useful aspect when assessing thermal stress on the vegetation. In this case, the Mann-Kendall statistical-relevance test was used in order to verify the relevance of the linear trends of the sets of data obtained from the three weather stations (Salmi et al., 2002). 
Two aridity indexes were also used in order to put the evolution of aridity in the study area into a context: the De Martonne aridity index ((calculated as I ar-DM $=\mathrm{P} /(\mathrm{T}+10)$, where $\mathrm{P}$ and $\mathrm{T}$ stand for precipitations $(\mathrm{mm})$, and average annual temperatures $\left({ }^{\circ} \mathrm{C}\right)$, respectively)) (De Martonne, 1926) and UNEP ((I ar-UNEP = P/PET, where P stands for average annual precipitations $(\mathrm{mm})$, and PET stands for potential evapotranspiration $(\mathrm{mm})$ calculated by means of the Thornthwaite method)) (Thornthwaite, 1948).

In addition, in order to analyze the direct link between climate (thermal) stress and changes at forest level, the WorldClim.org database was used to spatially represent average annual temperatures (calculated over a time span of 50 years, i.e. 1950-2000) against $1-\mathrm{km}$-sized cells (the highest resolution available from the respective data platform). The climate data on that global platform are similar, for the biggest part, to the data available from ECA\&D (for instance, an analysis of the values of the pixels around the three weather stations - representing the multi-annual mean average of temperatures - indicates that there is a similarity to the multi-annual mean average of ECA\&D values at the respective weather stations), considering that WorldClim data are obtained by way of measurements conducted at weather stations and matched against the digital elevation model (SRTM).

Starting from the assumption that, in the area analyzed, average annual temperatures above $11.5^{\circ} \mathrm{C}$ cause thermal stress to the forest vegetation, we attempted to establish connections between the number of pixels of the average temperatures above that value and the number of pixels that registered a loss in vegetation density, as obtained by change-detection analysis in the two time spans analyzed (taking into consideration the entire time span analyzed, 1990-2011). The respective threshold was selected because it represents a limit-factor in terms of the environmental needs of false acacia (the main forest species in the study area, the reason why the analysis of that thermal threshold value was generalized to span the entire study area), as the favorable-climate (thermal) conditions for that species stand roughly in the $9-11.5^{\circ} \mathrm{C}$ range (Calafat, Poiana Mare, Jiana forestry-planning documents).

The limited precipitation may be another climate variable that may influence forest-vegetation desiccation, but in this scenario the probability was discarded as a result of the fact that in the study area the lowest multi-annual precipitation mean values (1950-2000) stand at $563 \mathrm{~mm}$, significantly higher than the $400 \mathrm{~mm}$ mean, the minimal value before disturbances tended to rise in the optimal functioning of false-acacia forest ecosystems.

In order to calibrate the data, the average-temperature spatial-data cells were resized to 30 $\mathrm{m}$, equivalent to the size of the NDVI index cells obtained from the Landsat satellite images. The entire analysis of the two variables encompassed 361 patches of forest, spanning the study area.

\subsection{NDVI data}

The NDVI index was calculated using Landsat 5 TM (Landsat 7 TM for the case of the year 2000) satellite images (path 184, rows 029 and 030), acquired from the glovis.usgs.gov platform. Thematic Mapper sensor was preferred thanks to its spatial resolution, which is much more appropriate to study relatively small territories, such as our study area. Unlike MODIS, which has much coarser spatial resolution, Landsat images represent a perfect balance between accessibility, spectral and spatial resolution. The images were acquired during 
the vegetation season, i.e. on July 11, 1990, June 28, 2000 and August 22, 2011, depending on their availability as determined by cloud presence. Although there is a certain gap in time between the satellite data acquired, caused by the synoptical conditions, the satellite images were taken during the peak season of vegetation growth, so that the possible differences in phenology of the forest ecosystems are small - during that time span - and the results obtained may be deemed viable. The satellite images were processed according to the standard radiometric-calibration and atmospheric-correction procedures for Landsat $5 \mathrm{TM}$ satellite images, used by the U.S. Geological Survey (Chander et al., 2007).

Selection of temporal interval is very important. The year of 1990 marks a bifurcation point in the historical evolution of the area. Before this landmark point the area had been evaluated within the conditions of deep agricultural and forestry control under communist regime. After 1990, the area was left to the mercy of fate: forestry and irrigation works were abandoned. Without land-improvement works, the impact of natural factors on the forests became much more significant and visible, while conservation works were almost ceased. Thus, without neglecting the importance of the ante-1990 period, we consider that post-1990 period is most suitable to study the effects of climate change in this area.

The NDVI index, calculated relatively simply by means of spectral bands 3 and 4 (NDVI $=N I R-r e d / N I R+r e d)$, is highly useful in the analysis of vegetation quality. In theory, its values range from -1 to +1 , but in practice the actual values range from approximately -0.8 to +0.9 . The negative values mean barren areas (no vegetation), with sand, barren rock or water, while positive values mean areas covered with vegetation. In general, positive values up to 0.1 mean low- and very-low-density vegetation, while values in the $0.11-0.2$ and 0.21 -0.3 ranges mean vegetation with average and relatively high density. Although, in general, values above 0.3 mean vegetation with very high density, forest ecosystems match values around 0.6 , at least as far as the temperate region is concerned (earthobservatory.nasa.gov).

In order to eliminate possible errors in the demarcation of forest ecosystems in terms of the NDVI index thresholds, the change-detection analysis was narrowed down to the limits of the patches of forests demarcated by the Corine Land Cover, 2006 edition (CLC, 2006), with their borders brought up to date by means of aerial scale photos, 2008 edition (NACREA, 2008). Another benefit of an analysis using the limits of the patches of forest is that, as the spatial data on the limits of forests are relatively up to date, it eliminates for the most part instances of human intervention (deforestation) which would have otherwise influenced the results obtained by means of the NDVI index, thus establishing a direct link between climate conditions and the change-detection analysis.

\subsection{Thermal stress}

The impact of thermal stress on NDVI was quantified using correlation and regression analyses. In the wake of spatial representation of the average annual temperature data (worldclim.org), one notices that they fall in the $10.1-12^{\circ} \mathrm{C}$ range. The highest values are registered in the southern part of the analyzed area, as well as along valleys (such as the obvious example of the Jiu River valley) (Figure 2), where there are frequent intrusions of warm-air masses coming in from the south, predominantly from Northern Africa, especially during the summer months (Ciulache, 2005). Taking into account that most of the forest ecosystems in the analyzed area consist of acacia species (Robinia pseudoacacia), an at- 
tempt was made to establish correlations between the average annual temperature values that impact on the normal development of that species, and the change-detection analysis of the NDVI index. According to the studies drawn as part of the local forest-administration services' reports (concerning acacia's environmental needs), the average annual temperatures above $11.5^{\circ} \mathrm{C}$ can be a problem for acacia forest species, and values above that limit act as an overall source of thermal stress for the patches of forest (Calafat, Poiana Mare, Jiana, Şimian forestry-planning documents). These values are predominantly found in the southern part of the area analyzed (the Oltenia Plain, Danube River meadow areas and the Jiu River meadow), spatially matching, for the most part, the changes in NDVI indexes (1990 and 2011). Thus, out of the total number of forest bodies found in our study area, just 191 fall within the area concerned (with temperatures above the threshold), which represented our target group.

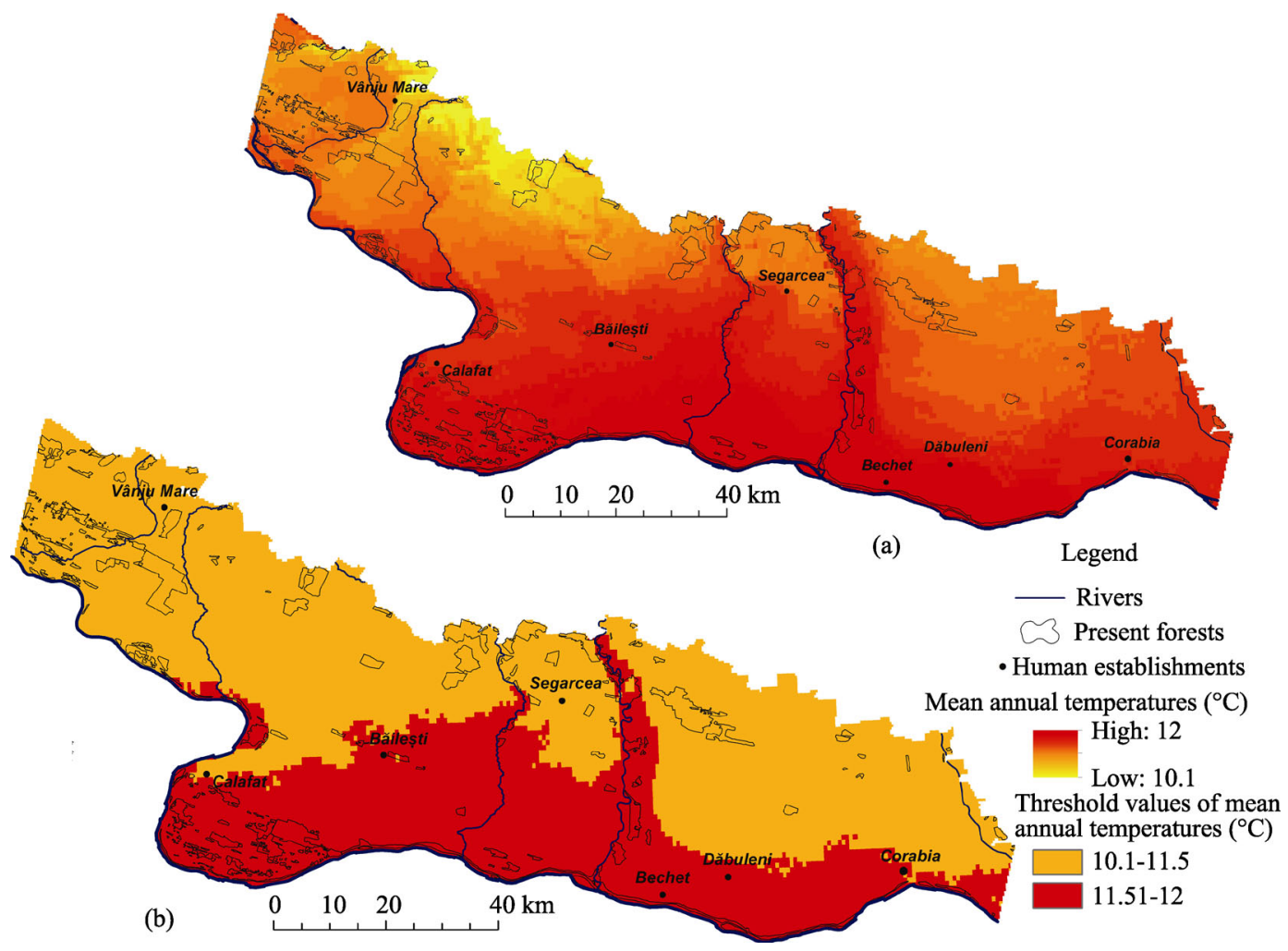

Figure 2 Spatial representation of average annual temperatures (1950-2000) in the analyzed area (a); spatial representation of threshold-values selected among average annual temperatures (b) (processed WorldClim.org data)

Thermal stress impacts the quality of forest biomass: it becomes less green, which is reflected in lowering NDVI values. We are concerned about what happened with the most dense forest vegetation. Have the NDVI declined in the past two decades? Does this decline relate to the temperature? In order to answer this question we recorded the number of pixels, in each of the forest bodies, for two cases: pixels having in 1990 NDVI values more than 0.5, and more than 0.55 , respectively, which diminished their values by 2011 . We used these data 
as dependent variable. As independent variable, we recorded the number of pixels, within each forest body, with the temperature higher than $11.5^{\circ} \mathrm{C}$.

The distribution of the raw data, NDVI and temperature, is not normal (see Figure 3a, for example). Regression analysis requires normally distributed data. Standardization included removing outliers (zeros for NDVI values) and log-transformations.
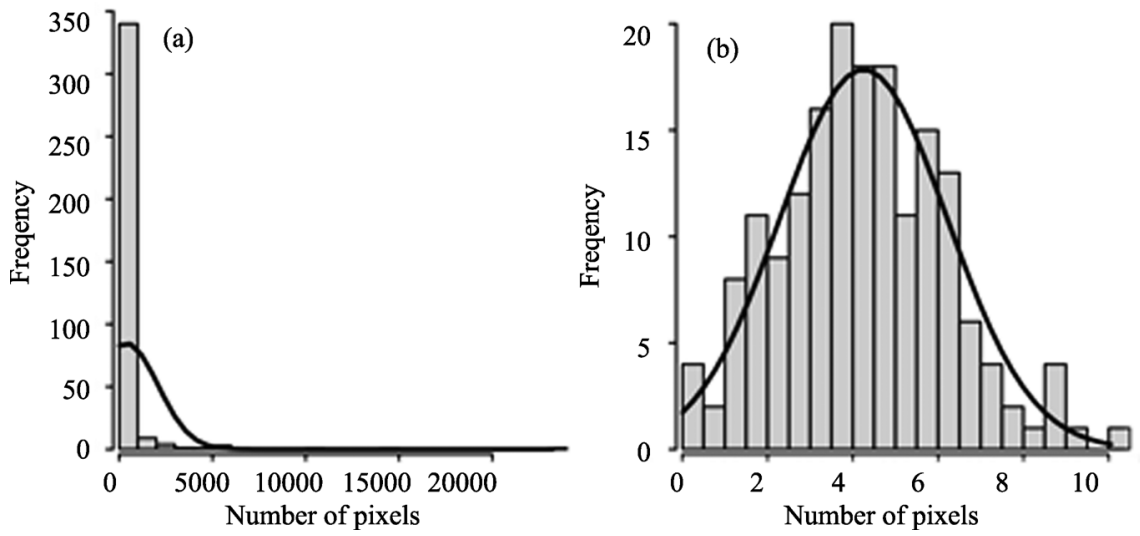

Figure 3 Example of data distribution (NDVI $>0.5$ ) before (a) and after (b) standardization

In addition, square root was extracted from log-transformed temperature data. Thus, all the variables fit normal distribution (see Figure $3 b$, for example), complying with the criteria of Shapiro and Wilk's test for normality (Royston, 1982). The final data sets (entries in the models) included 176 observations for NDVI $>0.5$ case and 157 observations for NDVI > 0.55 case.

\section{Results}

\subsection{Climate fluctuation}

From the point of view of climate fluctuation, during the time span analyzed (1961-2009) there stand out changes in climate conditions, predominantly in the past two-three decades. According to the results obtained by means of the vectorized grid method (Cheval et al., 2003), one notices a pronounced rise in average monthly temperatures, predominantly after 1990, in general at the beginning and the end of the vegetation season (April and October), but also during the season of peak biological activity (May through August) (Figure 4).

In the case of the average monthly precipitations, one notices a drop starting 1980, in general during the vegetation-season months (April-October). Thermal stress during the time of maximal biological activity (May-August) was analyzed so as to ensure better comprehension of the trends of climate fluctuation and the impact on vegetation (Figure 5). Subsequently, one can notice a clear upwards trend in average monthly temperatures during May-August, with the trends growing particularly sharper in the past three decades. According to the Mann-Kendall statistical-relevance test (Salmi et al., 2002), the linear trends are relevant for very high relevance landmarks, that is for $\alpha=0.001$ (the maximal relevance value) in the case of the Drobeta and Turnu Măgurele weather stations, and $\alpha=0.01$ in the case of the Craiova weather station. 
I II III IV V VI VII VIII IX X XI XII

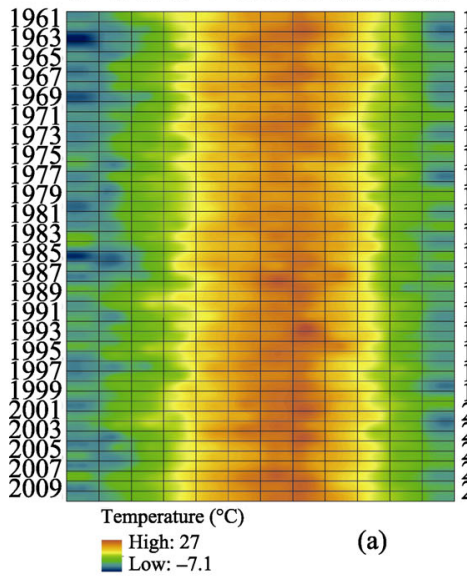

I II III IV V VI VII VIII IX X XI XII

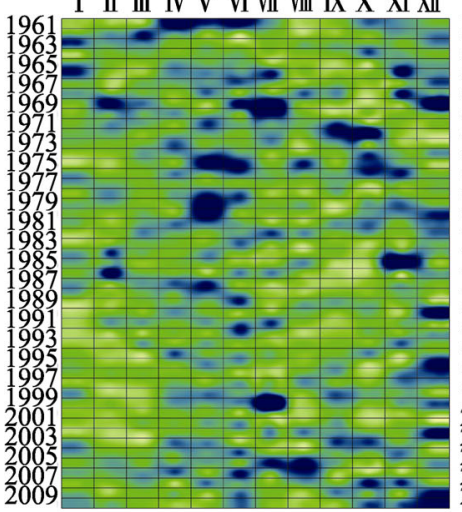

Rainfall (mm)

High: 331.4
Low: 0.1

(b)
I II III IV V VI VII VIII IX X XI XII

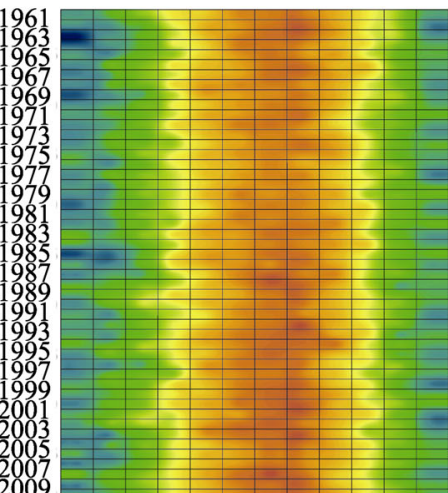

Temperature $\left({ }^{\circ} \mathrm{C}\right)$

- High: 26.5

(c)
I II III IV V VI VII VIII IX X XI XII

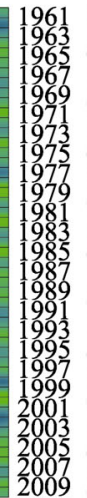

Temperature $\left({ }^{\circ} \mathrm{C}\right)$

High: 26.7

(e)

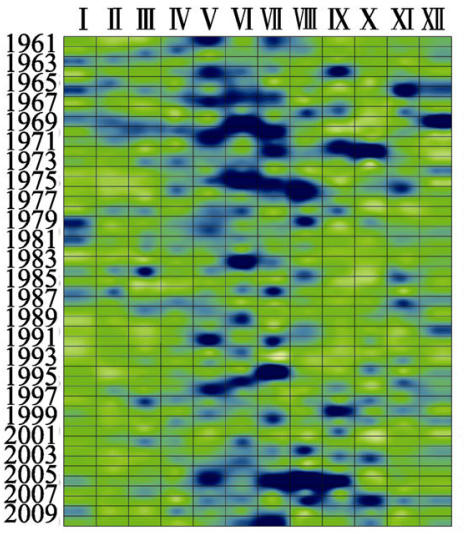

Rainfall (mm)

High: 232
Low: 0.1

(d)
I II III IV V VI VI VII X X XI XII

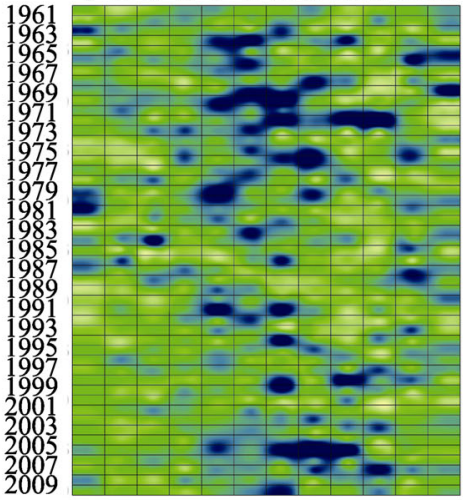

Rainfall (mm)

High: 199.3
Low: 0

(f)

Figure 4 Annual fluctuation of the average monthly temperatures and precipitations (1961-2009), at the Drobeta Turnu Severin (a, b), Craiova (c, d) and Turnu Măgurele (e, f) weather stations

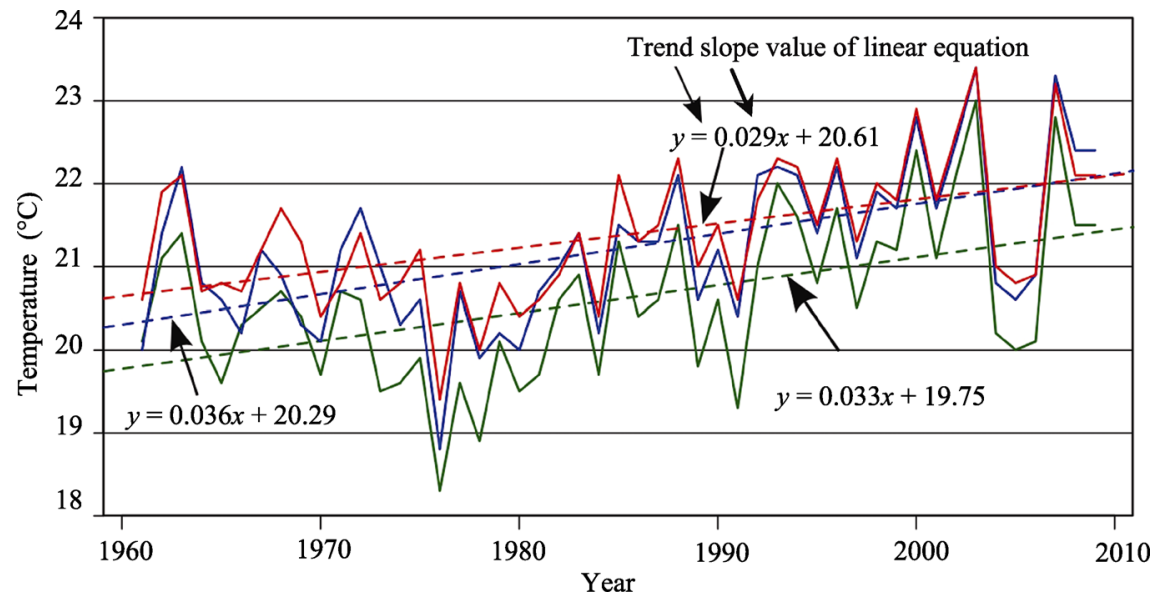

Figure 5 Annual fluctuation (1961-2009) of average monthly temperatures, during the time of peak biological activity (May-August) 
Looking at the overall situation, the analysis of the De Martonne and UNEP aridity indexes (Figures 6a and $\mathrm{b}$ ) reveals the increasing trend of climate aridization in the past few decades. The De Martonne aridity index offers a downtrend in values, which means heavier aridization (De Martonne, 1926). The most visible downtrend in De Martonne index values occurs after 1980 when values start fluctuating in the 10-15 and 15-20 ranges, ranges typical of semi-arid and dry steppe climate conditions, according to the De Martonne classification.
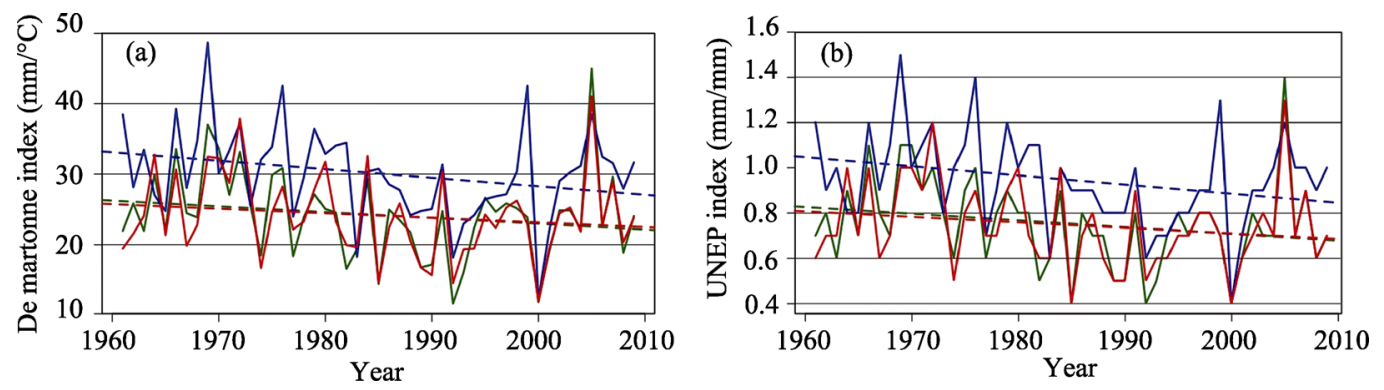

Figure 6 Multi-annual fluctuation of the De Martonne (a) and UNEP (b) aridity indexes and linear trends at the Craiova, Drobeta Turnu Severin and Turnu Magurele weather stations (1961-2009)

The values of the UNEP aridity index also register a downtrend (in a similar manner, the lower the values, the drier the climate). Starting with the 1980s, the index values frequently fall in the 0.2-0.5 range, a range typical for the presence of a semi-arid climate (UNEP, 1992).

\subsection{NDVI change detection}

Change-detection analysis of the forest ecosystems in the past two decades is very important because, in general, that period coincided with accelerated changes at the level of the climate parameters. The NDVI index is a viable method of assessing the changes that occur at the level of the vegetation's spectrum response, and it offers opportunities for the analysis of the vegetation in terms of its development. Because the values below 0.3 are typical of less developed vegetation, the analysis focused on values above 0.3 , typical of very-high-density vegetation, and, to a certain extent, of forest ecosystems (earthobservatory.nasa.gov).

Thus, the comparative analysis of 1990 and 2011 reveals a $20 \%$ decrease in the size of the high-density-vegetation areas, i.e. from 459,460 ha ( $62 \%$ of the total area under study) by 1990 to around 299,450 ha $(40 \%)$ by 2011 (Figure 7). However, the values above 0.3 only match forest ecosystems to a certain extent, as it is deemed that values around 0.6 would be adequate to use to demarcate forests in terms of the NDVI index, in the case of temperate areas (earthobservatory.nasa.gov).

In this situation, the change-detection analysis at the level of the patches of forest was conducted at values above 0.5 and 0.55 , deemed more suitable, since using 0.6 would have limited the consistence of forest vegetation a lot. In this respect, the analyses were conducted for three distinct time periods: for 1990-2000, for 2000-2011 and for all of 1990-2011. Therefore, an analysis of the state of changes during 1990-2000, for the 0.5 threshold, reveals a $13.5 \%$ decline in the consistency of forest vegetation (7620 ha); in case 


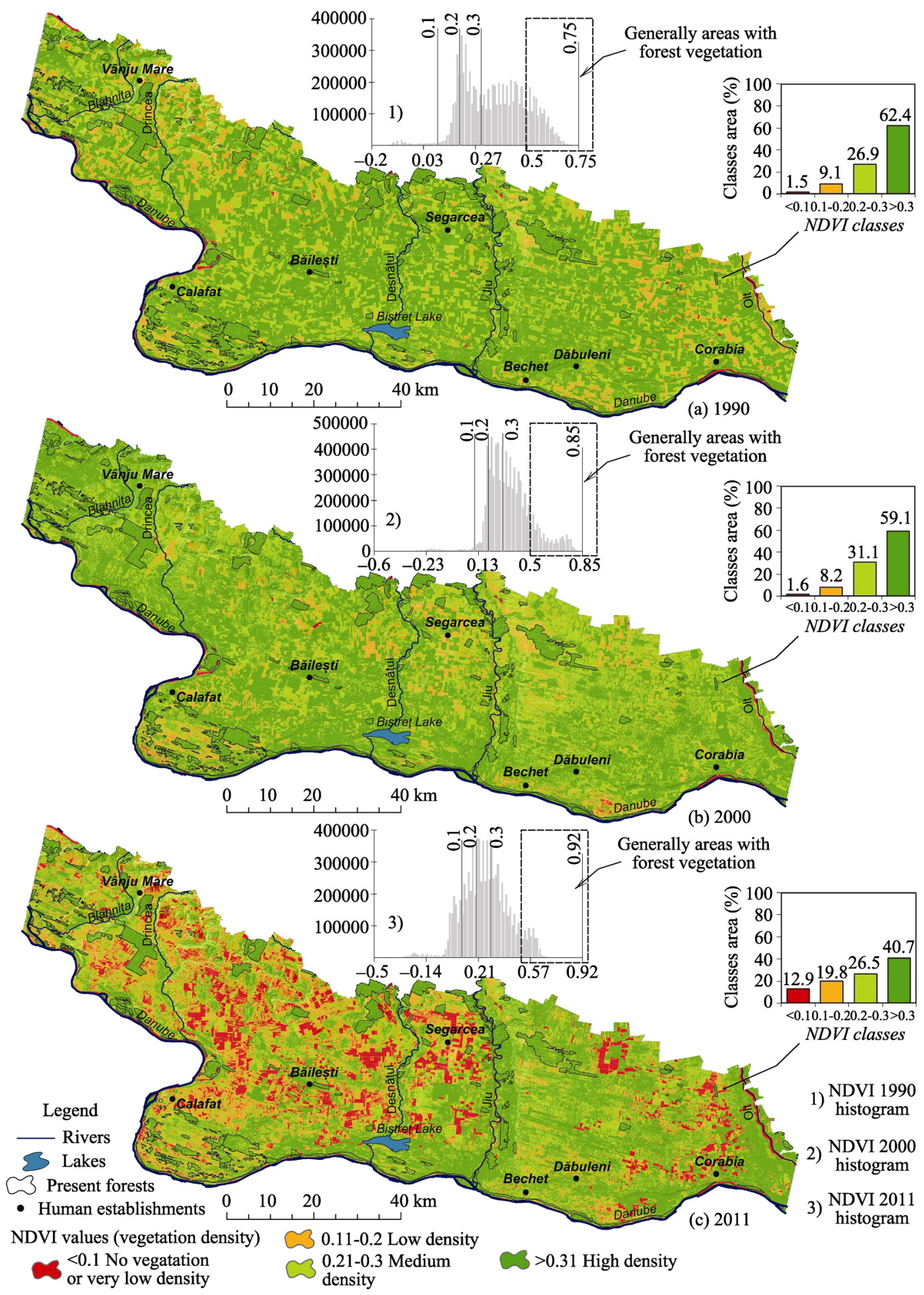

Figure 7 Spatio-temporal evolution of the NDVI index during 1990-2011 


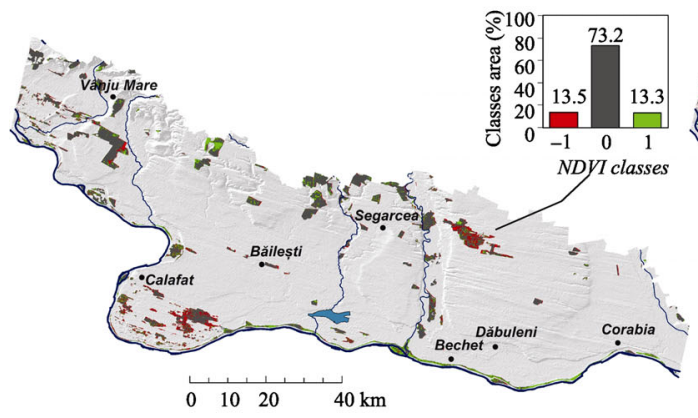

(a) NDVI 1990-2000 changes (0.5)

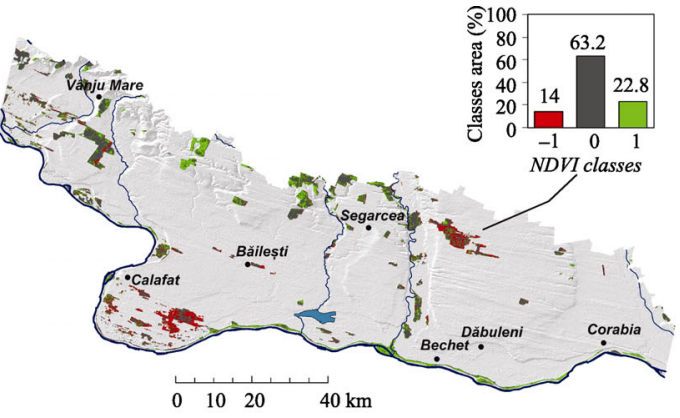

(b) NDVI 1990-2000 changes (0.55)

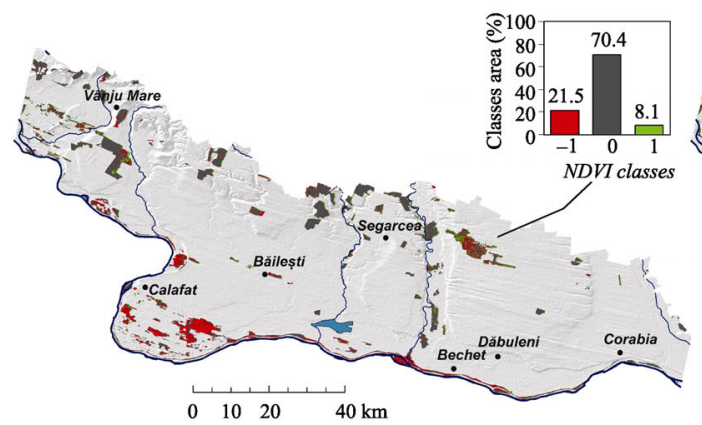

(c) NDVI 2000-2011 changes (0.5)

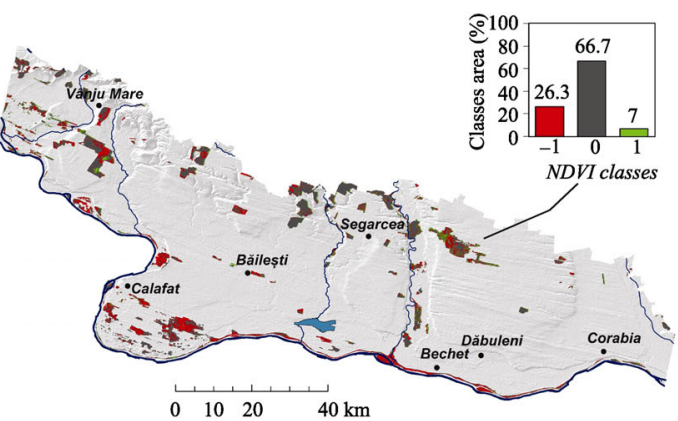

(d) NDVI 2000-2011 changes $(0.55)$

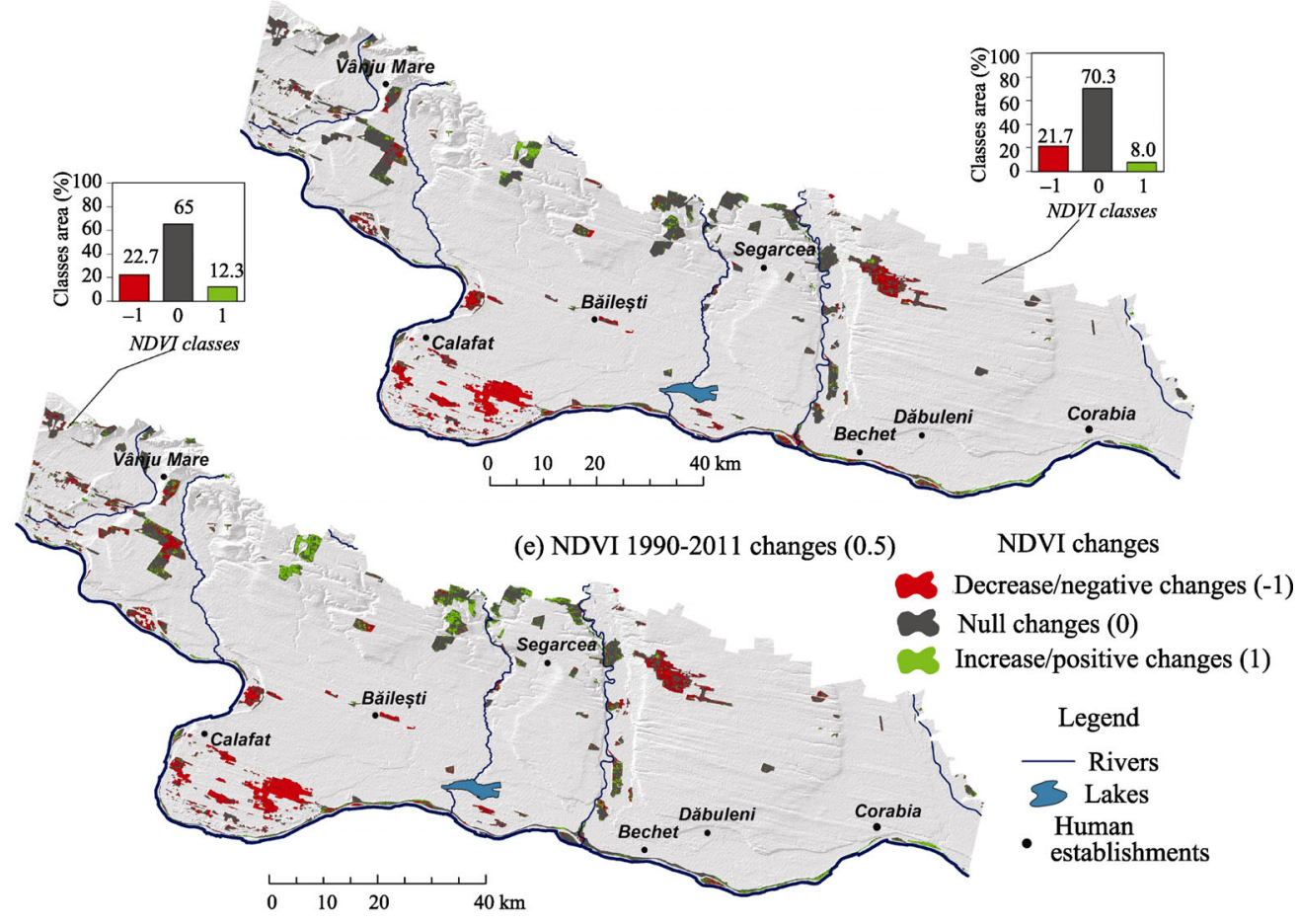

(f) NDVI 1990-2011 changes (0.55)

Figure 8 Change-detection analysis in terms of the NDVI index during 1990-2011 
of the 0.55 threshold, the loss amounts to $14 \%$ (7869 ha) (Figure 8). Significant differences emerge in the 2000-2011 period, too, that is a $21.5 \%$ drop $(12,109$ ha) in the case of the 0.5 threshold and $26.3 \%(14,843 \mathrm{ha})$ in case of the 0.55 threshold.

The entire time span analyzed, 1990-2011, reveals a loss of 12,230 ha (for 0.5 NDVI index), which means almost $22 \%$ of the total forest surface (Figure 8). At a higher value (0.55), the index values' losses in surface rise to about $23 \%$, a percentage equal to an area of 12,803 ha. Location-wise, the steepest drops in NDVI index values during 1990-2011 occurred in the southern part of the area analyzed (south of the town of Calafat, areas in the Danube River meadow), but also in the western part (west of the Drincea River) and in the northeast (east of the Jiu River) (Figure 8).

On the other hand, mention must be made there have also been positive changes in the NDVI index value, predominantly in the northern part of the region, in that part of the Getic Plateau that is included in the study area. Quantity-wise, during 1990-2000 the gains amounted to 7467 ha $(13.3 \%)$, and 12,867 ha $(22.8 \%)$, respectively, for the 0.5 and 0.55 thresholds, while during the 2000-2011 period the values registered for the two thresholds stand at 4544 ha $(8.1 \%)$ and 3925 ha (7\%), respectively. For the entire time span analyzed, the gains amount to a surface of 4493 ha (8\%) for values above 0.5 , while for values of 0.55 the gains rise by $35 \%$ (2424 ha), amounting to a total 6917 ha (12.3\% of the total surface of the forests) (Figure 8).

\subsection{The influence of climate stress on changes in the NDVI index values}

Correlation analysis, applied on the standardized data showing the number of pixels with NDVI loss and temperature above $11.5^{\circ} \mathrm{C}$, shows quite a moderate, significant though, positive correlation between the variables (Table 1). Positive correlation supports our hypothesis that the larger the area with high temperatures, the more extended the decline of NDVI values within the forest bodies.

Table 1 Output of NDVI vs. temperature linear regression models for two cases: NDVI $>0.5$ and NDVI $>0.55$

\begin{tabular}{ccccc}
\hline Case & Correlation coefficients & Intercept & Slope & $95 \%$ confidence interval for slope \\
\hline NDVI $>0.5$ & 0.625 & -6.45 & 4.51 & {$[3.99 ; 5.04]$} \\
NDVI $>0.55$ & 0.618 & -7.40 & 4.81 & {$[4.25 ; 5.38]$} \\
\hline
\end{tabular}

Linear regression models (Figure 9) result in two quite similar equations. Slope coefficient for the case NDVI $>0.55$ (Figure 9b) is bigger than for NDVI $>0.5$ (Figure 9a) that might suggest higher sensitivity of more dense vegetation to thermal stress.

Their variability depending on sampling was assessed using ordinary nonparametric bootstrap simulation with 1000 replicates (Davison, Hinkley, 1997). It shows that slope coefficients for each of the two cases can vary within about $+/-0.52,+/-0.56$ respectively, with $95 \%$ probability (Table 1 ). The models were validated using 10 -fold cross-validation. The resulted root mean square error of prediction of all the folds is 1.45 pixels for NDVI $>$ 0.5 and 1.6 pixels for NDVI $>0.55$.

The results of statistical modeling definitely point to the fact that thermal stress negatively impacts the quality and spatial distribution of forest biomass. 

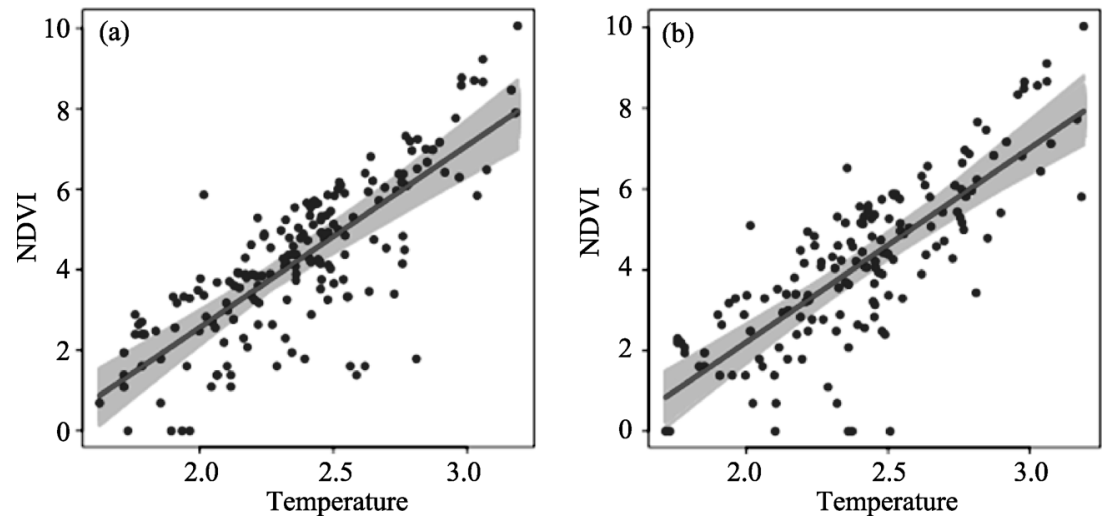

Figure 9 NDVI vs. temperature $\left(>11.5^{\circ} \mathrm{C}\right.$ ) (both measured in number of pixels per forest body): a) for NDVI $>$ 0.5 ; b) for NDVI $>0.55$. Legend: blue points - observations; red line - regular regression line; gray array - regression lines for each of 1000 bootstrap replicates

\section{Discussion}

The climate analysis work in the present study, concerning the year-on-year fluctuation of average annual temperatures and precipitations, has indicated that the general trend is one of the rising temperatures and declining precipitations, and that the direct effects are visible in the ecological quality of the forest ecosystems. The relatively high values of the correlation quotients $(\mathrm{r}=0.62)$ between average annual temperatures above the $11.5^{\circ} \mathrm{C}$ threshold (a threshold deemed to cause thermal stress on the main forest species, the acacia) and the changes at the level of NDVI indexes, establish a direct link between the current climate stress and the deterioration of forest quality.

Therefore, thermal stress, amplified during the vegetation season, is the determining thecause for the desiccation (degradation) of forest species, and it is the direct effect of the aridization of the climate in the area analyzed. Climate aridization has particularly intensified during the past few decades (Dumitraşcu, 2006; Prăvălie et al., 2013b; Prăvălie et al., 2013b) and it is connected to the quasi-natural global causes (climate change) (IPCC, 2007), but also to the local climatic particularities. These particularities mainly consist of an irregular fluctuation of the precipitations and frequent warm-air advections (typically from Northern Africa), especially during summertime (which causes temperatures to rise to $40^{\circ} \mathrm{C}$ and higher), all of these combining to cause aridity and drought in the plains regions (Ciulache, 2005), and the ensuing destruction of forest species. In general, the high temperature levels also have other indirect effects that impact on the bigger ecosystem, upon the rise of the evapotranspiration rates (Bandoc and Golumbeanu, 2010; Bandoc, 2012).

Nevertheless, there are also related reasons for the deterioration of forests, a deterioration that consists of the desiccation of forest species on sizeable tracts of land. In the regions located in the western part of the area analyzed (west of the Blahnita River) the decline of the local base level, as a result of the construction of the Portile de Fier II hydro-power plant upriver on the Danube, is one important cause for the desiccation of the acacia and poplar species (Jiana, Şimian forestry-planning documents). At the same time, the soil's weak humidity retention, in the sand interdune, semi-endoreic areas (the sandy-soil regions) is yet 
another cause for the desiccation of forest species.

Sandy soils, located on a total 116,000 ha $(16 \%$ of the total study area) in the southern, western and central-eastern regions, are yet another factor limiting the extent of the patches of forest. During June-September, as a result of the frequent hot days (temperatures above $30^{\circ} \mathrm{C}$ ), the temperature of the uppermost sand layer rises to around $60-70^{\circ} \mathrm{C}$, with disastrous effects, especially on saplings (Calafat, Poiana Mare, Şimian, Jiana forestry-planning documents).

Mention must be made that the positive changes in the NDVI index values match a relative improvement in quality of the forest ecosystems, but this situation is limited to small areas in the central northwestern region of the study area. This situation is mainly due to the geographical conditions, different from those elsewhere in the analyzed area, conditions caused by the high altitude (up to $240 \mathrm{~m}$ ) of the plateau landforms (the Getic Plateau), compared to the plains region (the Oltenia Plain). This particularity has brought about, in that region, the presence of ecological conditions more favorable to forest ecosystems, its main features being lower average annual temperatures (below $11^{\circ} \mathrm{C}$ ), more precipitations (up to $640 \mathrm{~mm} /$ year) and a lower evapotranspiration rate than elsewhere in the analyzed area.

Mention should also be made that other forest species, such as Canadian poplar (Populus Canadensis), found on sizeable areas, may be even more vulnerable to desiccation (degradation), considering that their favorable environmental conditions from the point of view of average annual temperatures fall approximately in the $9.5-10.5^{\circ} \mathrm{C}$ range. Thus, it is very likely that Canadian poplar forests located in the areas with the highest multi-annual average temperatures (up to $12^{\circ} \mathrm{C}$ ), may have been even more severely impacted by thermal stress over the past few decades.

One should also point out that aridization is a phenomenon that must be approached in a multidimensional manner, as aridization also contributes to the weakening of other environmental/territorial systems, by multiplying the negative environmental, economic and social effects. Research into the causes that contribute to the amplification of the effects is one of the priorities of contemporary society, and the results can not be overlooked when drafting territorial management strategies, that should contribute to alleviating the negative effects (Peptenatu et al., 2011; Ianoș et al., 2012).

\section{Conclusions}

Climate aridization in Southwestern Romania is a topical phenomenon in specialized research works, as it has major negative environmental and social effects. The rise of average annual temperatures, and especially the rise of summertime temperatures, has caused important damages to forest ecosystems, particularly endangering their bioproductivity. The analysis of the connections between climate stress and the modifications that emerged at forest level in the past two decades has revealed that there is a strong link between the two environment variables, at least as far as the time span analyzed is concerned. Changedetection analysis of the forest vegetation, by means of the NDVI index, has revealed that thermal stress is the main cause for the deterioration/desiccation of the forest species, (particularly acacia, the predominant forest species), mainly in the southern part of the study area. The deterioration of the forest ecosystems in the western and northeastern regions was 
partly due to other related causes, too, such as changes in the local base level and the presence of sandy soils, causes that acted in a distinct manner, but with the same result, the desiccation of forest species.

Considering that the demarcation of the forest borders used the most up-to-date information available, and the entire change-detection analysis was conducted within the forest's spatial borders, climate stress remains the main cause responsible for the changes at the level of the NDVI indexes in the two time spans, as human-intervention causes were for the most part disregarded. Therefore, starting from the premise that the forest boundaries reflect the existing zoning context and scale, and that potential anthropogenic pressures (deforestation) were minimal after 2008, heat stress can be considered to be the main cause for forest ecosystem quality shifts, although the human factor can not be excluded completely.

At the same time, it was considered that among climate factors temperature is the main climate parameter to have impacted on the optimal functioning of forest ecosystems, because other important factors, such as precipitations, fulfill the environmental needs of most forest species. Those needs consist of at least 400-500 mm/year (according to the reports of the local forest-administration services), and, according to the WorldClim database, average annual precipitation in the region including the study area range from 563 to $639 \mathrm{~mm}$.

Therefore, the causes of the global climate changes, as well as some local changes, have acted unidirectionally to disrupt forest ecosystems. Under these conditions, steps to redress the situation are necessary, at least as far as local factors are concerned, as the phenomenon of global climate changes is an unpredictable one and almost impossible to control.

\section{Acknowledgements}

The authors are thankful for the valuable comments coming from anonymous referees who had the patience to review earlier versions and thus considerably helped revise this paper. This work was supported by the project Territorial Management Based on Growth Poles Theory (UEFICSU-PNII-Idei, 1950) and the contract POSDRU/86/1.2/S/57462, strategic project "Optimization of the insertion process on the labour market concerning the geography graduates", co-financed by the European Social Fund, through the Sectoral Operational Programme for the Human Resources Development 2007-2013.

\section{References}

Anyamba A, Tucker C J, 2005. Analysis of Sahelian vegetation dynamics using NOAA-AVHRR NDVI data from 1981-2003. J. Arid Environ., 63: 596-614.

Archaux F, Wolters V, 2006. Impact of summer drought on forest biodiversity: What do we know? Ann. For. Sci., 63: $645-652$.

Bandoc G, 2012. Estimation of the annual and interannual variation of potential evapotranspiration. In: Evapotranspiration: Remote Sensing and Modeling. InTech., 251-272.

Bandoc G, Golumbeanu M, 2010. Climate variability influence to the potential evapotranspiration regime of Sfantu Gheorghe Delta Shore. Journal of Environmental Protection and Ecology, 10(1): 172-181.

Barbosa H A, Huete A R, Baethg W E, 2006. A 20-year study of NDVI variability over the Northeast Region of Brazil. J. Arid Environ., 67: 288-307.

Chander G, Markham B L, Barsi J A, 2007. Revised Landsat-5 Thematic Mapper Radiometric Calibration. IEEE Geoscience and Remote Sensing Letters, 4: 490-494. 
Cheval S, Baciu M, Breza T, 2003. An investigation into the precipitation conditions in Romania using a GIS-based method. Theoretical and Applied Climatology, 76: 77-88.

Ciulache S, 2005. Câmpia Olteniei. Clima. Geografia României, Vol. V, Editura Academiei Române.

Cui L, Shi J, 2010. Temporal and spatial response of vegetation NDVI to temperature and precipitation in eastern China. Journal of Geographical Sciences, 20(2): 163-176.

Dale V H, Joyce L A, McNulty S et al., 2001. Climate change and forest disturbances. BioScience, 51: 723-734.

De Martonne E, 1926. Une nouvelle fonction climatologique: L' indice d'aridite. La Meteorologie, 2: 449-458.

Deshayes M, Guyon D, Jeanjean H et al., 2006. The contribution of remote sensing to the assessment of drought effects in forest ecosystems. Ann. For. Sci., 63: 579-595.

Dumitraşcu M, 2006. Modificări ale peisajului în Câmpia Olteniei. Editura Academiei Române, Bucureşti.

Gao Z Q, Dennis O, 2001. The temporal and spatial relationship between NDVI and climatological parameters in Colorado. Journal of Geographical Sciences, 11(4): 411-419.

Hanson P, Weltzin J, 2000. Drought disturbance from climate change: Response of United States forests. Sci. Tot. Environ., 262: 205-220.

Holle B V, Joseph K A, Largay E F et al., 2006. Facilitations between the introduced nitrogen-fixing tree, Robinia pseudoacacia, and nonnative plant species in the glacial outwash upland ecosystem of Cape Cod, MA. Biodiversity and Conservation, 15: 2197-2215.

Ianoș I, Peptenatu D, Pintilii R D et al., 2012. About sustainable development of the territorial emergent structures from the metropolitan area of Bucharest. Environmental Engineering and Management Journal, 11: $1535-1545$.

IPCC, 2007. Climate Change 2007: The Physical Science Basis. Contribution of Working Group I to the Fourth Assessment Report of the Intergovernmental Panel on Climate Change. Cambridge, Cambridge University Press, 996p.

Iverson L, Prasad A, Matthews S, 2007. Modeling potential climate change impacts on the trees of the northeastern United States. Mitigation and Adaption Strategies for Global Change, 13: 487-516.

Keller F, Lischke H, Mathis T et al., 2002. Effects of climate, fire, and humans on forest dynamics: Forest simulations compared to the paleological record. Ecol. Model., 152: 109-127.

Lee B, Kim S Y, Chung J et al., 2008. Estimation of fire severity by use of Landsat TM images and its relevance to vegetation and topography in the 2000 Samcheok forest fire. J. For. Res., 13: 197-204.

Li J, Lewisa J, Rowland J et al., 2004. Evaluation of land performance in Senegal using multi-temporal NDVI and rainfall series. J. Arid Environ., 9: 463-480.

Li Z, Guo X, 2012. Detecting climate effects on vegetation in northern mixed prairie using NOAA AVHRR 1-km time-series NDVI data. Remote Sens., 4: 120-134.

Liu X, Ren L, Yuan F et al., 2012. Assessing vegetation response to drought in the Laohahe catchment North China. Hydrology Research, 43: 91-101.

Meng M, Ni J, Zong M, 2011. Impacts of changes in climate variability on regional vegetation in China: NDVI-based analysis from 1982 to 2000. Ecol. Res., 26: 421-428.

Moshki A, Lamersdorf N P, 2011. Symbiotic nitrogen fixation in black locust (Robinia Pseudoacacia L.) seedlings from four seed sources. Journal of Forestry Research, 22(4): 689-692.

Păltineanu Cr, Mihăilescu I F, Seceleanu I et al., 2007. Using aridity indexes to describe some climate and soil features in Eastern Europe: A Romanian case study. Theoretical and Applied Climatology, 90: $263-274$.

Pătroescu M, 2005. Câmpia Olteniei. Vegetaţia şi fauna. Geografia României, Vol V. Editura Academiei Române.

Peptenatu D, Pintilii R D, Draghici C, 2011. Environmental risk management of urban growth poles regarding national importance. International Journal of Environmental Science and Technology, 8: 737-746.

Peptenatu D, Sîrodoev I, Prăvălie R, 2013. Quantification of the aridity process in South-Western Romania. Journal of Environmental Health Science and Engineering, 11: 5, Iran.

Prăvălie R, 2013a. Climate issues on aridity trends of Southern Oltenia in the last five decades. Geographia Technica, 17(1): 70-79.

Prăvălie R, 2013b. Considerations about the reduction of marshes in Southern Oltenia. Geographia Technica, 18 
(2): 71-79.

Prăvălie R, 2013c. Aspects regarding spatial and temporal dynamic of irrigated agricultural areas from Southern Oltenia in the last two decades. Present Environment and Sustainable Development, 7(2): 133-143.

Prăvălie R, Peptenatu D, Sîrodoev I, 2013a. The impact of climate change on the dynamics of agricultural systems in South-Western Romania. Carpathian Journal of Earth and Environmental Sciences, 8(3): 175-186.

Prăvălie R, Sîrodoev I, Peptenatu D, 2013b. Changes in the forest ecosystems in areas impacted by aridization in South-Western Romania. Journal of Environmental Health Science and Engineering. (in press)

Salmi T, Määttä A, Anttila P et al., 2002. Detecting trends of annual values of atmospheric pollutants by the Mann-Kendall test and Sen's slope estimates: The Excel template application MAKESENS. Finnish Meteorological Institute, Helsinki, Finlanda.

Sternberg T, Tsolmon R, Middleton N et al., 2011. Tracking desertification on the Mongolian steppe through NDVI and field-survey data. International Journal of Digital Earth, 4(1): 50-64.

Traci C, 1985. Împădurirea Terenurilor Degradate. Ceres Bucureşti ed.

UNEP, 1992. World Atlas of Desertification. London, UK: Edward Arnold.

Virtanen R, Luoto M, Rämä T et al., 2010. Recent vegetation changes at the high-latitude tree line ecotone are controlled by geomorphological disturbance, productivity and diversity. Global Ecology and Biogeography, 19: $810-821$.

Vogelmann J E, Xian G, Homer C et al., 2012. Monitoring gradual ecosystem change using Landsat time series analyses: Case studies in selected forest and rangeland ecosystems. Remote Sensing of Environment, 122: 92-105.

Wang J, Rich P M, Price K P, 2003. Temporal responses of NDVI to precipitation and temperature in the central Great Plains, USA. Int. J. Remote Sens., 24: 2345-2364.

Wang L, Wei Y, Niu Z, 2008. Spatial and temporal variations of vegetation in Qinghai Province based on satellite data. Journal of Geographical Sciences, 18(1): 73-84.

Yang Z, Gao J, Zhou C et al., 2011. Spatio-temporal changes of NDVI and its relation with climatic variables in the source regions of the Yangtze and Yellow rivers. Journal of Geographical Sciences, 21(6): 979-993.

(1997) Jiana forestry-planning document. General Study. Institutul de Cercetari si Amenajări Silvice Voluntari.

(2004) Calafat forestry-planning document. General Study. Institutul de Cercetari si Amenajări Silvice Voluntari.

(2004) Poiana Mare forestry-planning document. General Study. Institutul de Cercetari si Amenajări Silvice Voluntari.

(2005) Orthophotomaps, 1:5000 scale. The National Agency of Cadastre and Real Estate Advertising (NACREA).

(2006) Corine Land Cover (CLC). European Environment Agency, www.eea.europa.eu.

(2010) Şimian forestry-planning document. General Study, Institutul de Cercetari si Amenajări Silvice Voluntari.

European Climate Assessment \& Dataset (http://eca.knmi.nl/dailydata/ customquery.php).

http://earthobservatory.nasa.gov/Features/MeasuringVegetation/.

http://forest.jrc.ec.europa.eu/activities/forest-ecosystem-services/.

http://www.worldclim.org/. 